\title{
ART
}

\section{YESTERDAY AND TODAY OF KAZAKH KUY}

\author{
PhD Student Bazheneyeva S. \\ Kazakhstan, Nur-Sultan, Kazakh National University of Arts \\ DOI: https://doi.org/10.31435/rsglobal_wos/30122019/6844
}

\section{ARTICLE INFO}

Received: 10 October 2019

Accepted: 19 December 2019

Published: 30 December 2019

\section{KEYWORDS}

History of Kazakhstan, history of Kazakh traditional music, art of Kuy,

kuyshi,

globalization and Kuy,

UNESCO 2003 Convention.

\begin{abstract}
The article discusses the history of the performance of the Kazakh kuy throughout the history of the separation of Kazakhs into a separate ethnic group to the present. Examples are provided to familiarize readers with the general context. Especially we focus on the Kazakh traditional forms of music-making.

Since in the 20th century kuy appeared on the stage and was placed within the framework of a European-style concert, this could not but leave an imprint on how kuy was perceived, influenced the situation in the life of the once nomadic society, in the system of its spiritual values and the viability of kuy, especially in an urban environment.

Now that the "Kazakh traditional art of dombra kuy" has been included in UNESCO's representative list, stakeholders need to take measures to safeguard the element of intangible cultural heritage.
\end{abstract}

Citation: Bazheneyeva S. (2019) Yesterday and Today of Kazakh Kuy. International Academy Journal Web of Scholar. 12(42). doi: 10.31435/rsglobal_wos/30122019/6844

Copyright: (C) 2019 Bazheneyeva S. This is an open-access article distributed under the terms of the Creative Commons Attribution License (CC BY). The use, distribution or reproduction in other forums is permitted, provided the original author(s) or licensor are credited and that the original publication in this journal is cited, in accordance with accepted academic practice. No use, distribution or reproduction is permitted which does not comply with these terms.

Historical review. As the historical review of Eurasian oikumene allows us to see, the Kazakh ethnos was part of the Turkic superethnos and shared a common culture until the middle of the $15^{\text {th }}$ century. This is the line that separated Kazakh musical culture from the common Turkic. As historian Mohamed Khaidar from the Dulat clan writes: "At that time, Abulkhair Khan ruled in Desht-i-Kipchak; the Jochi sultans were very ill from him, and two of them Janibek Khan and Girey Khan fled to Mogolistan. IsaBuga-Khan received the refugees well and gave them the edge of Chu and Kozy-Bashy, which makes up the western outskirts of Mogolistan" [1]. Many clans left their fertile homelands of Desht-i-Kipchak because of civil strife, clashes and raids, following Kerey and Janibek, formed the Kazakh ethnos.

From then on, the separation of the historical processes of culture, art and literature, once formerly united, begins. Kazakh, Nogai and other peoples cultivate creators whose art, based on the traditions of their ancestors, will reflect a new reality. In their works we see bitterness about the lost unity, sadness about abandoned relatives in their native lands, parting words to rulers and soldiers for the preservation of peace and the further prosperity of the people, eg. dombra kuys like "Parting of Kazakhs and Nogais", "Death of Khan Ormanbet and farewell to ten clans of Nogais", etc. The names of the authors of these kuys erased time, so they exist as folk. Along with this, there are no musical notes of kuys, since musical and poetic art existed and was transmitted orally. Even if time did not spare the names of the creators of these historical kuys, the folk memory and guardians of tradition the bearers of culture - preserved and passed on the heritage to each subsequent generation.

Kuys are performed on various folk musical instruments, such as kobyz, sybyzgy, saz syrnai, zhetigen and others. However, the most common kuy performed on a dombra, "Kazakh dombra - twostringed plucked chordophone, having a long neck with fret bandages. A method of sound production - the entire game is his right hand or a pinch" [2]. Its appearance varies slightly depending on 
spreading region. Now in the modern world, many Kazakh families, even those living abroad, who have moved in connection with historical events or search of a better life, have dombra in their homes.

Now it is the time to move on to the very concept of kuy. Kuy is a spiritual legacy, as well as a cultural heritage of Kazakhs. Translated from Kazakh kuy means "condition of mood, state of feeling". Since the sound is invisible and at the same time affects not so much the consciousness, but rather the person's subconscious, the Kazakhs perceived the performance of the kuy as a connection with the Creator, calling the kuy "Kuy - Tanirding kubiri" (the whisper of God). Some philosophical kuys can immerse listeners in a meditative state.

There are many stories, when the sounds of the dombra, performing the kuy, healed the souls of people, bring the mourners back to life. A vivid illustration of the given example is such a case. "One day, the only son of generous Kushikbay bai (wealthy man) died. Broken by grief, not seeing the point of living, the bai stopped eating and drinking and lay down waiting for his dying hour. So a month goes by. Concerned relatives gathered a council, they decided to call kuyshi Tattimbet, since only he can dispel a father's grief. Tattimbet arrived in the bai's aul (village), without uttering a word, sat at the threshold of the yurt and began to perform kuy. So, he continuously performed a cycle of 62 kuys. As soon as the kuyshi finished playing everything, Kushikbay felt that his grief was dissipating, and he got out of bed. They say that he was surprised to see a young man in front of him and said: "I thought that my grief is the worst in the world, but when I heard your kuy, I realized that grief is worse than mine and that a person should live no matter what. Where does the grief in your kues come from?" And then Tattimbeta answered: "Your grief is the grief of one man, but I carry the grief of all the people in me"' [3]. These were the kuys of the Kosbasar genre belonging to Tattimbet Kazangapuly - the great kuyshi of the 19th century, who was also a fair arbiter, diplomat, gold miner....Here, according to tradition, the kuy itself should sound, since the performance was always carried out by the legend, story about the origin of Kuy or any narrative to adjust perception.

Mostly, kuys performed during konak asy (ceremonial reception of guests). Mukhambetova defines this as a kind of "frame", which is a separator of everyday life and time when guests and hosts communicate. During the reception, refreshments, music, everyday conversations, jokes, preaching teachings of elders, aloud reflections on life and art are interspersed. The inclusion of playing music in the form of communication of a broader plan stipulated that the musician never acted only as an author and performer. Under these conditions, the story before the performance of the kuy on the dombra sets the listeners in a necessary mood and provides a full perception of music [4].

Such was the traditional culture of kuy performance before Kazakhstan became part of the USSR. Before the form of management changed and the Kazakhs switched from nomadism to settled. The process of urbanization began and the people started to move from the countryside to the cities. As a result, the form of music existence has changed.

Transition to Modernity. From the starting point of the October Revolution in 1917 Kazakhs underwent through tragic historical events, such as dispossession, collectivization, hunger, repression of the intelligentsia, World War II, which claimed the lives of most of the Kazakhs [5]. Even though the people were placed in rather harsh social conditions, culture did not cease to exist and develop, however, as it was then required by ideology, in new and unnatural forms for traditional music.

In 1934, a philharmonic society was opened in the city of Alma-Ata, and the Kurmangazy folk instrument orchestra was formed by renowned composer, academic Akhmet Zhubanov, in which the leading role belongs to the dombra and kobyz groups. It was supposed to be a multifunctional orchestra - on the one hand, to represent national music in traditional timbre sounding, and on the other - to perform orchestral music by European composers. In this regard, it was necessary to create improved dombra and kobyz.

Based on the diatonic dombra, a chromatic instrument was created with a pear-shaped body and a long neck with 21 perne (fret). This type came to be called the dombra tenor. At the same time, varieties of dombra were created, such as bass, double bass. Kobyz was so modified that, instead of two strings of horsehair were four strings tuned to violin harmony and timbre was close to the violin.

The orchestra began to play the repertoire, mostly consisting of cues of the West Kazakhstan dombra school tokpe (kuy that flows and spills over, originated from the verb "togu" - to pour, spill).

Zhubanov did a lot to maintain the traditional art in the city in an authentic, "pure" way. Traditional professional musicians were attracted and assembled from different parts of Kazakhstan to create it. Along with his orchestra, traditional soloists performed on stage - dombrists, singers. 
The fame and popularity of the Kurmangazy folk instrument orchestra among the people remained until the 60s. Further, the most important changes in the mass consciousness of the Kazakhs regarding the Europeanization of culture, its impact on traditional values, and the preservation of cultural identity led to serious research on ancient folk instruments in the $70 \mathrm{~s}$. The pioneer and popularizer was Bolat Sarybaev. He conducted scientific activities [6], and also created an ensemble of performers on ancient instruments and gave lectures and concerts.

All this activity paved the way for a new phenomenon. In 1981, the "Otyrar Sazy" folk instrument orchestra was created. Revived instruments like sybyzgy, sazsyrnai, sherter, kernei, and many others were introduced into it. This changed the overall timbre of the orchestra's sound, bringing it closer to the people's favorite soft, matte sound. If the orchestra named after Kurmangazy was a symbol of progress, dynamic changes in cultures on the path of europeanization, then "Otyrar Sazy" affirmed the antiquity of culture, its depth, and originality. This was manifested in the timbre sound of the orchestra, the repertoire, which was based on the traditional works of Southern and Eastern Kazakhstan. The appearance of the orchestra was formed by the talented dombrist and composer Nurgissa Tlendiev.

Tlendiev also created a new type of concert. His orchestral compositions are more chamber in sound, which corresponds to the aesthetics of traditional musical communication; during the concert, he talked with the audience, told the stories of the creation of his works, shared his thoughts, actively attracted listeners to complicity. This created an atmosphere that is close to the traditional music-making.

In subsequent years, ensembles were created consisting of ancient instruments, which, following the path laid by their predecessor orchestras. However, one of them stands apart. This is the "Murager" ensemble, organized by Abdulhamit Raimbergenov. The ensemble offered its version of traditional music in the urban context, performing kuys and songs in a unified-heterophonic sound, in which individual solo tones, alternating, come to the fore.

In the concerts of the ensemble, the group performance alternate with the solo of kuys and songs. This ensemble represents those shifts in the understanding of traditions that have occurred:

- the attitude to traditional culture as a value that no modernized and westernized forms can compensate for;

- the realization that traditional music in the city should exist in various forms, satisfy the tastes of various groups.

Orchestra named after Kurmangazy, "Otyrar Sazy" and plenty of ensembles in different sorts are existing nowadays as well. Even new musical phenomena created since the begging of the third millennium. Namely, so-called "DEKKO" - performing kuys on dombra, and later authors' pieces, accompanied by synthesized sound arrangement in various ways. This genre invented by Zhasaral Ensepov is an abbreviation of Kazakh words, where "D" stands for "dombra", "E" for "estrada", "K" for "kuy", second "K" for "computer" and "O" for "performer" (oryndaushy).

Also, there are a lot of bands, groups and ensembles which performing kuys at stages of all variety: festivals of contemporary ethnic and world music, rock, pop and jazz music concerts, etc. This will bring us to a discussion of value first and foremost among Kazakh people and preserving people's spirituality and identity in the modern world especially from the perspective of the UNESCO 2003 Convention.

Conclusions. The UNESCO 2003 Convention is aiming to safeguard the Intangible Cultural Heritage of Humanity. Kazakhstan has ratified the Convention on $28^{\text {th }}$ of December 2011 [7]. In 2014 first element "Kazakh traditional art of dombra kuy" inscribed in the Representative List of ICH. However, creating the Lists and including an element into them is not the main purpose of adoption the Convention. Every and every State Party "shall take the necessary measures to ensure the safeguarding of the intangible cultural heritage present in its territory" [8]. We omit all the other important provisions, described in the Convention, in this article because it needs particular and thorough study on its own.

We would like to analyze and discuss the current situation of kuy's viability in modern Kazakhstan. Of course, the lineage of kuy performance on a stage in a concert form still exists. Nevertheless, the frequency of concerts, which truly aim to bring the form of playing music to traditional, is low. It is overpowered by forms of fused traditional music. Music in the DEKKO genre is gaining mass popularity. We see this as a reflection of the technical process and attempts to attract the attention of young people to dombra music (no matter in what form and quality of content) and making it trendy among them.

Undoubtedly, thanks to technological progress, a recording and sound-reproducing technique has appeared, which has brought benefits, since now we can listen to the masterpieces of world music (including Kazakh traditional music) anywhere and anytime. Also, we are witnessing that dombra in 
many cases becomes only as a representative, a sign of belonging to a particular culture. It means that traditional music started to serve for entertainment mostly. Gradually, it may substantiate as applied art, that it had never been before. In this regard, it should be noted that many philosophers believe that "the technology - it is just a technology, it all depends on the person who uses it."

Recording and selling finished music products has become an industry that is the backbone of many economies. The sales market is the whole world, thanks to globalization. However, traditional music does not fit into the concept of products for consumption, the same circumstance makes it possible to circumvent the support of traditional music as unprofitable. Although here we can talk about values that are much more important for the ethnos, which makes up the main population of the state.

Of course, these processes require detailed and thorough culturological and musicological evaluation. It is also necessary to develop a clear and concrete strategy for safeguarding the elements of the intangible cultural heritage of all ethnic groups living in the Republic of Kazakhstan.

We have touched only upon a tip of the iceberg called "Kazakh traditional kuy" and showed just a brief history of its transformation. It is not possible to dive into a profound musical culture which has a centuries-long history and overcome all stages of its development and changes under social processes. However, in the frame of the article, we could have posed some questions for our subsequent work.

\section{REFERENCES}

1. Haidar, M. (2003). Tarikh-i-rashidi (translated from a Persian manuscript). Almaty: Turan. (in Kazakh)

2. Utegalieva, S. (2006). Horodophones of Central Asia. Almaty: Kazakaparat. (in Russ.)

3. Nauryzbayeva, Z. (2019, June 19). Tattimbet. Retrived from http://otuken.kz/tattimbet/ (in Russ.)

4. Amanov, B., Mukhambetova, A. (2002). Kazakh Traditional Music and the $20^{\text {th }}$ century. Almaty: DaikPress. (in Russ.)

5. Tatimov, M. (1989). Social conditioning of demographic processes. Alma-Ata: Nauka. (in Russ.)

6. Sarybaev, B. (1978). Kazakh Musical Instruments. Alma-Ata: Zhalyn. (in Russ.)

7. Kazakhstan Ratified the Convention. (2012, 20 January). Retrived from http://ru.unesco.kz/kazakhstanratified-the-convention

8. Convention for the Safeguarding of the Intangible Cultural Heritage. (2003). https://ich.unesco.org/en/convention 